\title{
The Relationship of Leg Muscle Explosive Power and Students Straddle Style Results at Universitas Riau
}

\author{
D H Wijaya ${ }^{1 *}$, Arsil $^{2}$
}

\author{
${ }^{1}$ Faculty of Education, Universitas Riau, Indonesia \\ ${ }^{2}$ Sport Science Faculty, Universitas Negeri Padang, Prof. Dr.Hamka, Padang, Indonesia \\ ${ }^{*}$ Corresponding author. Email: heruwijayadedi@gmail.com
}

\begin{abstract}
The form of this study is a correlational study with population of 2011 university students in the health education team in Riau University which was taken using total sampling technique which involved 30 people. The instruments used in this study were vertical jump test and high jump result. Then the data was processed statistically, for the normality test with a reliability test at a significant level of $\alpha 0,05$, the hypothesis proposed is the relationship of vertical jump with high jump results. Based on the results of the research conducted, it can be concluded that limb muscle explosive power has a significant relationship with the results of the straddle force. It was obtained that tobserved $2.53>\mathrm{t}$ table 1.701 . Consequently, Ho is rejected and $\mathrm{Ha}$ is accepted. Besides, the results of the product moment calculation show that $\mathrm{r}$ count was 0.43 .
\end{abstract}

Keywords: Leg muscle explosive power, students straddle style

\section{INTRODUCTION}

Athletic sports are sports that grow and develop together with natural human activities. These athletic sports include running, jumping, and throwing. These three branches are an inseparable part of human life. Athletics is the original event of the first Olympics in $776 \mathrm{BC}$ which can be called the ancient Olympics where the only event is a race or stade. In the Greek era, running activities were not only religious activities but were also contested to obtain gifts from the king. Even to achieve it not only through victory, but sometimes death for the losers.

High jump rolling style, also known as straddle style, is one style in high jump which is still used in competitions and is taught in schools. Since the advent of the flop style, the popularity of the straddle style has begun to decline and has never been used again in big races. The difference in straddle style with other styles is seen from its implementation when crossing the bar which requires the feet to be opened wide before the landing. In other respects, the difference lies in the repulsive feet used in this style and lands with swing feet. From the posture during the air, the straddle style can be divided into two types, namely horizontal straddle and arch/dive straddle (Muhajir: 2003).

On the other hand, explosive power concerns the strength or speed of muscle contraction that is dynamic and involves the removal of maximal muscle mass in the fastest time possible (Ismaryati: 2008). Power is the ability of muscles that direct maximum strength in a very short time (Harsono: 1988). Explosive power is the muscle strength to direct maximum strength in repetitive and very fast activities.

From the opinion above, the writer can conclude that explosive power is the ability to direct power quickly in a short time to provide dynamic muscle contraction and the best momentum in the body or object in a repetitive motion to achieve the desired goal or result.

To support explosive power capabilities, the components of the physical condition are needed to achieve maximum results such as: 1) strength, 2) speed, 3) agility, 4) endurance, 5) muscle power. (Ihsan. 2017)

Muscle is an organ / tool that allows the body to move. This is an important characteristic of an organism. Cell movement occurs because the cytoplasm changes shape. This cytoplasm is long fine threads. If muscle cells can stimulate it will shorten itself towards a certain direction (Syafrudin: 1992).

Muscle contractions can contract muscle quickly. If you get stimuli from outside in the form of electrical current stimulation, mechanical heat, cold stimulation, and others. In everyday situations the muscles work or contract according to the influence or command that comes from the motor nervous system.

Among the muscle and bone veins, there is a mucus called the mucosal bursa which contains lenders which are useful for smoothing the veins to friction against the 
bones, while also facilitating the movement of the muscles towards the position of the bones. Diaphragm of the tendonium muscular structure that separates the thoracic cavity and abdominal cavity which forms the floor of the thoracic cavity or abdominal cavity. Diaphragm arises from the fetebralumbar through two curvature columns and from the surface in the xipoid process and the inner surface of the 6 lowest rib pairs. Of these three ribs are curved and form part of tendinium in the middle (Syafruddin: 1992).

The upper limb muscles have a very strong covering membrane and are called faisalata divided into three groups, namely: 1) the abductor muscle, 2) the extensor muscle, 3) the flexor femoris muscle.

1. On the other side, the lower limb muscle consists of several muscle forms including:

2. The shin muscle front of the anterior muscle functions to lift the edge of the middle leg and bend the leg.

3. The extensor talangusmusculuslongus functions to align the index finger half of the finger, ring finger and little finger.

4. the back calf muscle (muskulustibialisposterius) which starts from the membrane between the bones and attaches to the base of the leg bone. Its function is to bend the foot of the heel joint and the sole of the foot inward. (Syafruddin: 1992).

Moreover, high jump is a form of movement jumping up by lifting the front foot up in an effort to bring the point of weight as high as possible and as fast as possible falling (landing) by doing repulsion on one leg to reach a certain height.

In high jump sports there are several styles that can be done by each athlete according to their abilities and abilities. This style is actually the attitude of the body when above the bar. The force in high jump is as follows: 1) the sissors style, 2) the straddle style, 3) flop style (Fosbury flop).

The straddle style includes a point of weight a little above the bar. So, it can be concluded that the higher the point of weight to be lifted, the more power is needed. Thus if the same repulsion force is deployed to jump with different styles, the one force will produce results that are better than the other. However, in terms of mastery of motion, the straddle style is much simpler than the flop style.

The difference in straddle style with the other styles is from the way it is implemented when crossing the bar, which requires that the legs be opened wide and until before the landing, the legs are still opened wide. In other respects, the difference lies in the rejects used in this style and landing with swing feet. From differences in posture during the air, the straddle style can be divided into two types, namely horizontal straddle and arch / dive straddle.

There are several elements of basic techniques that can influence high jump, including prefix, repulsion, posture over the bar, and landing. In addition to the accuracy factor of jumping, leg strength, explosive power, and body shape of the jumper itself also influence (Muhajir: 2006).

\section{METHOD}

This research was conducted using a correlational research design that aims to investigate how far the variables on a factor are related to other factors. Correlational is a study designed to determine the level of relationship of different variables in one population and to test to find out how much the contribution between the independent variable and the dependent variable (Arikunto: 2002).

Population is the whole subject of research, if someone wants to examine all the elements in the research area, then the research is a population research (Arikunto: 2002). Arikunto said if the subject is less than 100 people, then sampling is determined by taking the entire population sampled. (total sampling) because of the small number of population, in this study it was made to take a sample of all 2011 male students of military education in the amount of 36 people.

The data taken in this study are data taken directly and obtained from the specified sample, namely in the form of numerical numbers from the results of vertical jump (explosive power) measurement of the high jump straddle style of male students of Penjaskesrek Riau University.

Based on the hypothesis proposed, data analysis is performed using product moment correlational analysis statistics. Before the data is analyzed first, the normality test is done by Lilliefors test and the linearity test of the regression equation at a significant level is 0 , 05 . Correlation analysis is used to prove the proposed research, while the correlation formula uses the product moment correlation formula by Pearson in Sudjana (1992).

After the data is obtained, it is analyzed descriptively, then the next is to test the research hypothesis proposed in accordance with the problem proposed. The hypothesis reads: there is a meaningful relationship between explosive limb muscle power (X) to straddle force (Y) in male students in the 2011 university of Riau. Based on data analysis obtained a correlation coefficient of r:0.43 where the meaning is tested by $\mathbf{t}$ test and $\mathrm{t}_{\text {count }}$ of 2.53 means $\mathrm{t}_{\text {count }}>$ $\mathrm{t}$ table 1.701 thus Ho is rejected and Ha is accepted.

Based on the hypothesis proposed that there is a relationship between explosive limb muscle power with straddle force results. After analyzing the data it turns out that $\mathrm{r}_{\mathrm{xy}}=0,43$ and the test $\mathrm{t}=2.53>\mathrm{t}$ table $=$ 1.701. Therefore it is categorized rather low. So the hypothesis proved that there was a relationship between explosive limb muscle power and straddle force results. 


\section{CONCLUSIONS AND RECOMMENDATIONS}

\section{Conclusion}

Conclusion: the hypothesis was accepted at a significant level of $\alpha 0.05$ in other words there was a significant relationship between explosive limb muscle power and straddle force results in 2011 college students in the health education team at the University of Riau.

\section{Means}

Based on the description above, that leg muscle strength and speed have a relationship with shooting ability, the researcher proposes the following suggestions:

1. It is expected that lecturers, 2011 university students, will do training in the fields of science related to the improvement of measurable sports achievements.

2. In an effort to increase the straddle style ability, the lecturers concerned must pay attention to the dominant component of physical conditions such as explosive limb muscle power because explosive limb muscle power is a component that is very important to be able to add straddle force results.

3. For the researchers themselves, this research may be continued in broader problems with a larger number of samples, so as to contribute ideas to lecturers and students to improve achievement.

\section{REFERENCES}

[1] Arikunto, Suharsini.2002. Prosedur Penelitian. (Edisi Revisi V). Jakarta: Rineka Cipta

[2] Harsono. 1988. Coaching Dan Aspek-aspek Psikologis Dalam Coaching. Jakarta: P2LPTK

[3] Ismaryati. 2008. Tes dan Pengukuran Olahraga. Surakarta: Lembaga Pengembangan Pendidikan (LPP) Universitas Sebelas Maret Press

[4] N. Ihsan, Yulkifli, Yohandri. 2017. Development of Speed Measurement System for Pencak Silat Kick Based on Sensor Technology. International Conference on Recent Trends in Physics 2016 (ICRTP2016) IOP Publishing. Journal of Physics: Conference Series 755 (2016) $011001 \quad$ doi:10.1088/17426596/755/1/011001

[5] Sudjana. 1992. Metode Statistika (Edisi Ke -5). Bandung: Tarsito.

[6] Syafruddin. 1992. Pengantar Ilmu Melatih. Padang: FPOK IKIP 